\title{
Sources of Iris yellow spot virus in New York
}

Cynthia L. Hsu, Department of Entomology, Cornell University, New York State Agricultural Experiment Station, Geneva, NY 14456; Christine A. Hoepting, Cornell Cooperative Extension, Cornell Regional Vegetable Program, Albion, NY 14411; Marc Fuchs, Department of Plant Pathology and Plant-Microbe Biology; and Erik A. Smith and Brian A. Nault, Department of Entomology, Cornell University, New York State Agricultural Experiment Station

\begin{abstract}
Hsu, C. L., Hoepting, C. A., Fuchs, M., Smith, E. A., and Nault, B. A. 2011. Sources of Iris yellow spot virus in New York. Plant Dis. 95:735-743.

Iris yellow spot virus (IYSV) has been found consistently in commercial dry bulb onion fields throughout New York State since 2006. Yearly recurrence of IYSV may result from annual reintroductions of the virus or persistence of the virus in overwintering host plants. To identify potential sources of IYSV, we surveyed onion transplants imported into New York as well as volunteer onion plants and weeds using a double-antibody sandwich enzyme-linked immunosorbent assay. IYSV was not found in any of 1,097 transplant samples tested in 2007 but 4 of $760(0.53 \%)$ transplant samples tested positive in 2008 .

IYSV was found in volunteer onion plants in 3 of 10 (30\%) onion fields sampled in 2007, in 4 of $27(15 \%)$ onion fields sampled in 2008, and in 6 of $12(50 \%)$ onion cull piles sampled in 2008. In all, 4 of 17 weed species (i.e., chicory [Cichorium intybus], common burdock [Arctium minus], curly dock [Rumex crispus], and dandelion [Taraxacum officinale]), were confirmed to be infected with IYSV using serological and molecular testing methods. IYSV may be reintroduced annually into New York through imported onion transplants but it also persists in volunteer onion plants and selected weed species.
\end{abstract}

Iris yellow spot virus (IYSV), from the genus Tospovirus in the family Bunyaviridae, causes significant yield losses and grade reductions in onion (Allium cepa L.) bulb and seed crops in the western United States $(9,11,12,15,28,38)$. Surveys of dry bulb onion fields in 2006 confirmed the presence of IYSV in New York State (20). Since then, IYSV has been found in onion fields across New York every year $(21,32,33)$. Because of the widespread distribution of IYSV at the time the virus was first detected, it is likely that the virus was present in New York before 2006.

Developing an effective, integrated management program for IYSV requires an understanding of basic epidemiological information about the virus pathosystem. This includes understanding primary infection sources, the mechanics of how the virus is transmitted from plant to plant, how the virus is introduced to new locations, how the virus survives between cropping seasons, and identifying factors that favor epidemics (24). Some of this information is known about Tospovirus spp. in general. Thrips are the only known vectors of Tospovirus spp., and acquire a Tospovirus sp. as larvae when feeding on infected plants $(23,52)$. The ability of larvae to become infective (i.e., to both acquire and successfully transmit a Tospovirus sp.) decreases with age of the larvae $(53,55)$. Tospovirus spp. replicate within the thrips host and are transmitted in a persistent, circulative manner; viruliferous adults are capable of transmitting a Tospovirus sp. to host plants for the duration of their lives (52). Aviruliferous adults feeding on infected plants can acquire Tospovirus spp. but cannot transmit the viruses $(37,57)$. There is no evidence of transovarial transmission of a Tospovirus sp. in thrips (58), and there is no evidence that Tospovirus spp. are seed transmitted (37). The spread of some Tospovirus spp. to new locations closely mirrors the dispersal of invasive thrips as vectors of the virus (37).

This general knowledge on Tospovirus spp. appears to hold true for the onion-IYSV-thrips pathosystem. More specific studies have confirmed that IYSV is not known to be transmitted through onion seed $(25,40)$, and the only confirmed vector for plant-toplant spread of IYSV is the onion thrips, Thrips tabaci (Lindeman)

Corresponding author: C. L. Hsu, E-mail: clh33@cornell.edu

Accepted for publication 16 February 2011.

doi:10.1094/PDIS-05-10-0353

(c) 2011 The American Phytopathological Society
$(6,25,30)$. Where onion plants are grown continuously and in close proximity for bulb and seed production, thereby creating a "green bridge", onion crops may be the primary sources of infection (37). In Colorado, IYSV incidence was very high in volunteer onion plants originating from the previous year's crops, and virus symptoms were detected on volunteer onion plants before appearing on the crop plants (16), suggesting that volunteer onion plants may be a primary source for infection. In Georgia, volunteer onion plants originating from infected bulbs imported from Peru and then culled were suspected to have been the primary source of IYSV when the virus was first detected in that state (36). In addition to infecting Allium spp., IYSV has been found in at least 21 non-Allium plant species (44) and, depending on the geographic region, these alternate host plants may be a primary source and a reservoir for the virus to persist after onion bulb crops are harvested. So far, research suggests that primary spread of IYSV is more important than secondary spread within onion crops, though limited secondary spread can occur $(16,37,45)$.

In New York, T. tabaci is the dominant thrips species in onion fields (14) but, in some other locations in the United States, multiple thrips species are common in onion fields $(10,31,46)$, or a species other than T. tabaci may dominate the onion system (36). For the onion-IYSV pathosystem in New York, there is relatively little information on the primary sources of infection, how the virus spreads to new locations, and whether the virus survives between onion cropping periods. The factors that favor epidemics of IYSV in New York are also unknown.

Onion is typically grown as a seed crop or a dry bulb crop; onion plants produce bulbs in the first season but produce flowers and seed in the second season if exposed to adequate vernalization (2). In New York State, the majority of onion production is for dry bulbs (39). Planting begins in April and May, and bulbs are harvested in late summer and fall. Bulbs are sold out of storage throughout the winter (39). Fields planted to onion crops in New York are usually not rotated with other crops, and onion crops are not grown in the fields over the winter. In New York, approximately $85 \%$ of the onion crop is grown from seed and $15 \%$ is grown using onion transplants (39). Most transplants are bare-root transplant seedlings imported from Arizona, where IYSV has been reported since 1993 (15). In Colorado, between 0.4 and $5.0 \%$ of onion transplant lots imported from Arizona and California had symptoms of IYSV, and 18 to $91 \%$ of the transplant lots sampled were infested with $T$. tabaci (15). The persistence of IYSV in New 
York could be associated with annual reintroductions of IYSV into this state if imported transplants are similarly infected or harbor viruliferous thrips.

Volunteer onion plants could serve as important overwintering hosts for IYSV, providing a reservoir for the virus each spring and enabling the virus to persist between onion cropping seasons. Volunteer onion plants originate from unharvested bulbs left in onion fields the previous season or from onion bulbs discarded in onion cull piles. Gent et al. (16) monitored volunteer onion plants that emerged from fields where IYSV had been documented the previous year, and found that almost all of the volunteers surveyed had IYSV symptoms. In New York, where onion crops are rarely rotated with other crops, onion volunteers could provide a consistent reservoir for IYSV each spring. Volunteer plants that develop in onion cull piles, created by growers and by packing houses from discarded bulbs, could also provide a spring reservoir for IYSV. In addition, bulbs grown outside New York from areas where IYSV is established, and imported into New York for repacking in packing houses, may include bulbs infected with IYSV (B. Nault, personal communication). Imported, infected bulbs that are culled could create another avenue for reintroduction of the virus into New York, similar to imported infected onion transplants. The potential of onion volunteers emerging in fields and cull piles to be sources of IYSV in New York has not been studied.

Other alternative overwintering host plants and potential reservoirs for IYSV during the growing season are weeds. IYSV has been found in numerous weed species in other states in the United States, and some of these weeds occur in New York; for example, common purslane (Portulaca oleracea L.) (7), redroot pigweed (Amaranthus retroflexus L.) (15), spiny sowthistle (Sonchus asper (L.) Hill) (35), green foxtail (Setaria viridis (L.) Beauv.) (13), common lambsquarters (Chenopodium album L.), kochia (Kochia scoparia (L.) Schrad.), and prickly lettuce (Lactuca serriola L.) (43). Preliminary studies have demonstrated that thrips that develop on IYSV-infected weeds can transmit IYSV to onion seedlings (46). The relative importance of weeds in the epidemiology of IYSV in New York is not known.

Table 1. Number of bare-root onion transplant samples imported from Arizona into New York that reacted positively for Iris yellow spot virus (IYSV) using a double-antibody sandwich enzyme-linked immunosorbent assay (DAS-ELISA) ${ }^{\mathrm{a}}$

\begin{tabular}{|c|c|c|c|c|}
\hline \multirow[b]{3}{*}{ Cultivar } & \multicolumn{4}{|c|}{ Number of samples ${ }^{b}$} \\
\hline & \multicolumn{2}{|c|}{2007} & \multicolumn{2}{|c|}{2008} \\
\hline & Tested & With IYSV & Tested & With IYSV \\
\hline \multicolumn{5}{|l|}{ Yellow bulb } \\
\hline Corona & 46 & 0 & $\ldots$ & $\ldots$ \\
\hline Empire Sweet & 69 & 0 & 60 & 0 \\
\hline Frontier & $\ldots$ & $\ldots$ & 60 & 0 \\
\hline Highlander & 130 & 0 & $\ldots$ & $\ldots$ \\
\hline Kasmer Homegrown & 136 & 0 & $\ldots$ & $\ldots$ \\
\hline Milestone & 143 & 0 & 60 & 0 \\
\hline Millennium & 46 & 0 & $\ldots$ & $\ldots$ \\
\hline Norstar & $\ldots$ & $\ldots$ & 120 & 1 \\
\hline Prince & $\ldots$ & $\ldots$ & 60 & 2 \\
\hline Ricochet & 43 & 0 & 60 & 0 \\
\hline Sherman & $\ldots$ & $\ldots$ & 60 & 0 \\
\hline $\mathrm{T}-439$ & $\ldots$ & $\ldots$ & 60 & 1 \\
\hline \multicolumn{5}{|l|}{ Red bulb } \\
\hline Mercury & 192 & 0 & 60 & 0 \\
\hline Red Bull & $\ldots$ & $\ldots$ & 40 & 0 \\
\hline Red Wing & 150 & 0 & 60 & 0 \\
\hline Red Zeppelin & 96 & 0 & 60 & 0 \\
\hline Rhumba & 46 & 0 & 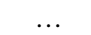 & $\ldots$ \\
\hline Total number & 1,097 & 0 & 760 & 4 \\
\hline
\end{tabular}

a Transplants of each cultivar were tested for IYSV before planting using a DAS-ELISA from Agdia Inc. (Elkhart, IN); ... indicates that no transplants were tested for that cultivar in that year.

${ }^{b}$ For number of samples tested, each sample consisted of green leaf material from five transplants combined into one composite sample.

c Total number of samples.
The primary goal of this project was to identify potential sources of IYSV in onion crops in New York. The specific objectives were to (i) estimate the incidence of IYSV in onion transplants imported into New York, (ii) estimate the incidence of IYSV in volunteer onion plants that emerge in spring in onion fields and cull piles in New York, and (iii) identify weed species in New York that may be potential hosts of IYSV.

\section{Materials and Methods}

Plant material. Plants were selected regardless of the presence or absence of symptoms, to provide unbiased estimates of the incidence of IYSV. All plant samples were stored at $4^{\circ} \mathrm{C}$ until analysis. All samples were collected in New York State and are identified by the county where they were collected. Plants collected from the "Elba muck", a large onion-growing region in two adjacent counties, are identified as originating from Genesee/Orleans Counties.

Bare-root onion transplants shipped into New York and tested in this study originated from two commercial farms in Arizona. In late April 2007, transplants of 11 cultivars (7 yellow and 4 red) were tested for IYSV (Table 1). For each cultivar, 30 plants were selected from each of 30 bundles of onion transplants containing approximately 50 to 100 plants/bundle. From this pool of 900 plants/cultivar, at least 200 plants/cultivar were selected for testing. Each sample consisted of 5 plants, and 1,097 samples (5,485 plants total) were analyzed for IYSV (Table 1). In late April 2008, 12 cultivars ( 8 yellow and 4 red) were tested for IYSV (Table 1). For each cultivar, 10 plants were selected from each of 45 transplant bundles. From this pool of 450 plants/cultivar, at least 200 plants/cultivar were tested. Similar to 2007, samples consisted of 5 plants/sample, and 760 samples (3,800 plants total) were analyzed for IYSV (Table 1).

Between late May and early June 2007, 231 volunteer onion plants were collected from 10 nonrotated onion fields located in Genesee/Orleans, Oswego, Wayne, and Yates Counties and tested for IYSV (Table 2). In May 2008, 578 volunteer onion plants were collected from 27 nonrotated onion fields in Genesee/Orleans, Orange, Oswego, Wayne, and Yates Counties and tested for IYSV (Table 2). During the same month, 359 volunteer onion plants were collected from 12 onion cull piles located in Genesee/Orleans, Orange, Oswego, and Wayne Counties and tested for IYSV (Table 2).

In July 2007, samples from 12 common burdock (Arctium minus Bernh.) and 4 dandelion (Taraxacum officinale G. H. Weber ex. Wiggers) plants were collected from weed banks adjacent to onion fields in Ontario and Yates Counties and tested for IYSV (Table 3). In spring 2008, 269 samples representing 10 weed species were collected from Genesee/Orleans Counties from the periphery of onion fields known to have a history of IYSV the previous year and tested for IYSV. In addition, 611 samples representing 11 weed species were collected from weed banks adjacent to onion fields in Orange County and tested for IYSV. In fall 2008, 414 samples representing nine weed species were collected from weed banks adjacent to onion fields in Genesee/Orleans Counties and tested for IYSV. In fall 2010, samples from 21 common burdock plants were collected in Yates County and tested for IYSV. Whole-plant samples were collected for each weed species except common burdock and stinging nettle (Urtica dioica L.). Because of the larger size of the plants, common burdock and stinging nettle samples consisted of leaves collected from the middle of each plant. Common and scientific names for each weed species (1) examined in this study are listed in Table 3.

Detection of IYSV by serological assays. Samples of imported onion transplants were analyzed as bulk samples, with tissue from five plants combined to create a 1-g composite sample. In almost all cases, transplants were large enough that only green leaf material was used in the composite sample. For larger transplants, tissue samples were taken from the middle of the plant by making slices perpendicular to the leaf and removing a section of each leaf. Volunteer onion plants collected from onion fields and cull piles were larger than the onion transplants and were analyzed as individual plants. Samples were taken from each plant by making a perpen- 
dicular cut to remove and discard the top two-thirds of the plant; then, a second, perpendicular cut was used to remove a section of each leaf from each plant as the sample to be tested. This method ensured that the sample included material from all leaves and, when present, the scape of each plant. All weed samples were analyzed as individual plants using small pieces of leaf material sampled from basal, middle, and apical leaves to form a composite sample for each plant. For common burdock and stinging nettle, where only leaves from the middle of the plant were collected, a thin section of each leaf cut perpendicular to the main vein was used to form a composite sample for each plant.

Plant samples were analyzed using a double-antibody sandwich enzyme-linked immunosorbent assay (DAS-ELISA) and commercially available antibodies for IYSV in onion (Agdia, Inc., Elkhart, IN). Plant samples were ground in a generic buffer composed of phosphate-buffered saline solution, $\mathrm{pH} 7.4$, supplemented with 0.2 mM sodium sulfite, $2 \%$ polyvinylpyrrolidone $40,000,90 \mathrm{mM}$ powdered egg albumin, and $2 \%$ Tween 20 . This buffer was later replaced with a commercially available premixed buffer, General Extraction Buffer 1 (GEB1; Agdia, Inc.), when lab studies showed that GEB1 was capable of detecting IYSV at higher dilutions of ground plant tissue than the generic buffer (C. Hsu, unpublished data). Plant tissue (1 g/sample) was ground in $10 \mathrm{ml}$ of buffer (1:10, wt/vol) using a semiautomated ball-bearing HOMEX tissue homogenizer (Bioreba, Reinach, Switzerland). Positive and negative control samples for IYSV were purchased from Agdia, Inc. All samples and the commercially purchased control samples were tested in duplicate wells, and the mean of the two readings was used in the data analyses. Substrate hydrolysis was stopped after 20 min using $50 \mu \mathrm{l}$ of $3.0 \mathrm{~N} \mathrm{NaOH}$. Optical density (OD) readings

Table 2. Number of onion fields and cull piles sampled in New York State in 2007 and 2008, number of volunteer onion plants tested, number of fields and cull piles with plants that reacted positively for Iris yellow spot virus (IYSV) using a double-antibody sandwich enzyme-linked immunosorbent assay (DASELISA), and incidence of IYSV in each positive field and cull pile

\begin{tabular}{|c|c|c|c|c|c|c|c|c|}
\hline \multirow[b]{2}{*}{ Year, county ${ }^{\mathbf{a}}$} & \multicolumn{4}{|c|}{ Volunteers sampled from onion fields } & \multicolumn{4}{|c|}{ Volunteers sampled from cull piles } \\
\hline & $\begin{array}{c}\text { Fields } \\
\text { sampled }^{b}\end{array}$ & $\begin{array}{c}\text { Plants } \\
\text { tested/field }\end{array}$ & $\begin{array}{c}\text { Fields } \\
\text { infected }^{\text {d }}\end{array}$ & $\begin{array}{l}\text { Incidence in } \\
\text { fields }(\%)^{\mathrm{e}}\end{array}$ & $\begin{array}{l}\text { Cull piles } \\
\text { sampled }\end{array}$ & $\begin{array}{c}\text { Plants } \\
\text { tested/cull pile }\end{array}$ & $\begin{array}{l}\text { Cull piles } \\
\text { infected }^{\mathrm{d}}\end{array}$ & $\begin{array}{l}\text { Incidence in } \\
\text { cull piles }(\%)^{\mathrm{e}}\end{array}$ \\
\hline \multicolumn{9}{|l|}{2007} \\
\hline Genesee/Orleans & 5 & $9-30$ & 1 & 4.3 & $\ldots$ & $\ldots$ & $\ldots$ & $\ldots$ \\
\hline Oswego & 1 & 8 & 0 & 0 & $\ldots$ & $\ldots$ & $\ldots$ & $\ldots$ \\
\hline Wayne & 1 & 15 & 1 & 6.7 & $\ldots$ & $\ldots$ & $\ldots$ & $\ldots$ \\
\hline West Genesee & 1 & 31 & 0 & 0 & $\ldots$ & $\ldots$ & $\ldots$ & $\ldots$ \\
\hline Yates & 2 & $4-80$ & 1 & 2.5 & $\ldots$ & $\ldots$ & $\ldots$ & $\ldots$ \\
\hline \multicolumn{9}{|l|}{2008} \\
\hline Genesee/Orleans & 15 & $14-30$ & 2 & $3.3,17.6$ & 4 & 30 & 3 & $3.3,3.3,6.7$ \\
\hline Orange & 6 & $24-30$ & 0 & 0 & 4 & 30 & 3 & $3.3,13.3,16.7$ \\
\hline Oswego & 2 & $15-20$ & 1 & 13.3 & 2 & $29-30$ & 0 & 0 \\
\hline Wayne & 1 & 30 & 1 & 10.0 & 1 & 30 & 0 & 0 \\
\hline West Genesee & $\ldots$ & $\ldots$ & $\ldots$ & $\ldots$ & 1 & 30 & 0 & 0 \\
\hline Yates & 3 & 30 & 0 & 0 & $\ldots$ & $\ldots$ & $\ldots$ & $\ldots$ \\
\hline
\end{tabular}

${ }^{\text {a }}$ Samples were collected from counties where major onion production is concentrated in New York; ... indicates that no samples were tested in that county and year.

${ }^{\mathrm{b}}$ Volunteer onion plants were only collected from fields that were planted to a dry bulb onion crop the previous year.

c Onion plants were tested individually.

${ }^{\mathrm{d}}$ A field or cull pile was considered positive for IYSV if at least one onion plant collected from that field or cull pile reacted positively for IYSV by DASELISA (Agdia Inc., Elkhart, IN).

${ }^{\mathrm{e}}$ Incidence is given as the percentage of plants tested in each field and cull pile that reacted positively for IYSV by DAS-ELISA.

Table 3. Weed species collected near onion fields in New York State in 2007 and 2008 and tested for Iris yellow spot virus (IYSV) using a double-antibody sandwich enzyme-linked immunosorbent assay (DAS-ELISA)

\begin{tabular}{|c|c|c|c|c|c|c|}
\hline \multirow[b]{2}{*}{ Plant family } & \multirow[b]{2}{*}{ Common name, Latin binomial ${ }^{b}$} & \multicolumn{5}{|c|}{ Year, location $(n)^{\mathrm{a}}$} \\
\hline & & $\begin{array}{l}\text { 2007, Ontario } \\
\text { \& Yates Cos. }\end{array}$ & $\begin{array}{l}\text { Spring 2008, } \\
\text { Orleans Co. }\end{array}$ & $\begin{array}{c}\text { Spring 2008, } \\
\text { Orange Co. }\end{array}$ & $\begin{array}{l}\text { Fall 2008, } \\
\text { Orleans Co. }\end{array}$ & $\begin{array}{l}\text { Fall 2010, } \\
\text { Yates Co. }\end{array}$ \\
\hline Apiaceae & Poison hemlock, Conium maculatum L. & $\cdots$ & $-(30)$ & & $-(60)$ & $\cdots$ \\
\hline Asteraceae & Common burdock, Arctium minus Bernh. & $+(12)$ & $+(30)$ & $+(60)$ & $+(60)$ & $+(21)$ \\
\hline Asteraceae & Canada thistle, Cirsium arvense (L.) Scop. & $\ldots$ & $\ldots$ & $-(60)$ & $\ldots$ & $\ldots$ \\
\hline Asteraceae & Chicory, Cichorium intybus L. & . & $+(27)$ & & $-(37)$ & $\ldots$ \\
\hline Asteraceae & Dandelion, Taraxacum officinale G. H. Weber ex. Wiggers & $+(4)$ & $+(29)$ & $+(60)$ & $+(60)$ & $\ldots$ \\
\hline Asteraceae & Canada goldenrod, Solidago canadensis $\mathrm{L}$. & $\ldots$ & $-(30)$ & $-(60)$ & $\ldots$ & $\ldots$ \\
\hline Asteraceae & Prickly lettuce, Lactuca serriola $\mathrm{L}$. & $\ldots$ & $\ldots$ & $-(60)$ & $\ldots$ & $\ldots$ \\
\hline Brassicaceae & Shepherd's purse, Capsella bursa-pastoris (L.) Medik. & $\ldots$ & $-(30)$ & $-(60)$ & $-(12)$ & $\ldots$ \\
\hline Brassicaceae & Virginia pepperweed, Lepidium virginicum L. & $\ldots$ & $\ldots$ & $-(60)$ & $\ldots$ & $\ldots$ \\
\hline Brassicaceae & Wild mustard, Sinapis arvensis L. & $\ldots$ & $\ldots$ & $\ldots$ & $-(60)$ & $\ldots$ \\
\hline Brassicaceae & Yellow rocket, Barbarea vulgaris Aiton $\mathrm{f}$. & $\ldots$ & $-(27)$ & $-(60)$ & $-(34)$ & $\ldots$ \\
\hline Caryophyllaceae & White campion, Silenelatifolia Poir. & $\ldots$ & $-(10)$ & $\ldots$ & $\ldots$ & $\ldots$ \\
\hline Lamiaceae & Purple deadnettle, Lamium purpureum $\mathrm{L}$. & $\ldots$ & $-(30)$ & $\ldots$ & $\ldots$ & $\ldots$ \\
\hline Malvaceae & Common mallow, Malva neglecta Wallr. & $\ldots$ & $\ldots$ & $\ldots$ & $-(60)$ & \\
\hline Polygonaceae & Curly dock, Rumex crispus L. & $\ldots$ & $\ldots$ & $+(60)$ & $+(31)$ & $\ldots$ \\
\hline Scrophulariaceae & Common mullein, Verbascum Thapsus L. & $\ldots$ & $\ldots$ & $-(11)$ & $\ldots$ & $\ldots$ \\
\hline Urticaceae & Stinging nettle, Urtica dioica $\mathrm{L}$. & $\ldots$ & $-(26)$ & $-(60)$ & $\ldots$ & $\ldots$ \\
\hline
\end{tabular}

a Numbers in parenthese indicate the total number of plants tested for IYSV by DAS-ELISA (Agdia Inc., Elkhart, IN) (plants were tested individually); ... indicates no samples of that species were collected that year; - indicates none of the plants reacted positively for IYSV by DAS-ELISA; + indicates at least one plant reacted positively for IYSV by DAS-ELISA. A subset of plants that reacted positively from this collection was tested separately using molecular techniques. Incidence of IYSV based on the DAS-ELISA results was not recorded due to inconsistent results using serological methods on non-Allium plants.

${ }^{\mathrm{b}}$ Names based on database maintained by the Weed Science Society of America (http://www.wssa.net/Weeds/ID/WeedNames/namesearch.php). 
were recorded at $405 \mathrm{~nm}$ using an MRX Microplate Absorbance Reader and Revelation software (DYNEX Technologies, Chantilly, VA) or a BioTek ELx808microplate reader (BioTek, Winooski, VT).

Variations to this standard DAS-ELISA protocol were used depending on the laboratory that prepared and analyzed the samples, as noted below. In 2007, the generic DAS-ELISA buffer was used to assay onion transplants; positive and negative control samples were tested in single wells, substrate hydrolysis readings were taken after 5 to $65 \mathrm{~min}$, and $\mathrm{NaOH}$ was not used. In 2008, all transplant samples were ground in GEB1 and analyzed using the standard protocol. In 2007, volunteer plant samples collected from onion fields were ground using GEB1 and analyzed using the standard protocol, except samples from a field in Yates County. Samples from Yates County were analyzed using the generic buffer, absorbance readings were taken after $5 \mathrm{~min}$, and $\mathrm{NaOH}$ was not used. In 2008, all volunteer onion samples were ground using GEB 1 but approximately $50 \%$ of the samples were ground in buffer at a $1: 10$ to $1: 20$ ratio (wt/vol) using $0.5 \mathrm{~g}$ of plant tissue and the other $50 \%$ were ground at 1:10 using $1 \mathrm{~g}$ of plant tissue. For volunteer onion plants collected from cull piles in 2008, two subsamples were taken from each plant collected. Each subsample was ground separately using GEB1 and analyzed using the standard protocol. The subsample with the highest OD reading was used in the analysis. In 2007, spring 2008, and fall 2010, weed samples were ground in the generic buffer using $0.5 \mathrm{~g}$ of plant tissue, ELISA plate readings were taken after $15 \mathrm{~min}$, and $\mathrm{NaOH}$ was not used. Weed samples collected in fall 2008 were ground using GEB1 and analyzed using the standard protocol.

In 2007, onion plant samples were considered positive for IYSV if the mean OD reading for the two sample wells was greater than three times the mean OD reading for the IYSV negative control sample for that plate. In 2008, data from onion transplant samples, volunteer plants from fields, and volunteer plants from cull piles were combined into one data set. Samples from 2008 were considered positive for IYSV based on the results of an expectation-maximization algorithm used to separate the combined data into two populations (27), as described by Hsu et al. (21). Raw data from each plate were standardized by subtracting the mean OD reading of the negative control samples for that plate from the mean OD reading for each sample on the plate. Standardized data were transformed using $\ln$ ([sample standardized OD reading $\times 1,000]+$ 100). The distribution of transformed samples was separated into negative and positive populations using "normalmixEM" (41). The population with the lower mean OD reading was considered the negative population. A threshold, $t$, was calculated using the estimated mean of the negative population (mean $=4.727$ ) plus four times the estimated standard deviation (sd) of the negative population ( $\mathrm{sd}=0.237$ ). Assuming that a Gaussian distribution is appropriate, this threshold, $t=5.674$, captures $99.99 \%$ of the negative data, minimizing the probability that a negative sample is incorrectly classified as positive for the virus. Samples with an ln-transformed value $>t=5.674$ were classified as positive for IYSV. This threshold is slightly higher than the $t=5.549$ threshold identified using the same procedure for onion plants collected from fields in Genesee/Orleans Counties between 2007 and 2008 (21).

DAS-ELISA results for weeds were used to identify weed species for further testing using molecular techniques. The incidence of IYSV in weeds was not calculated from the DAS-ELISA results because serological tests using antibodies developed for onion to analyze weed samples gave inconsistent results (C. Hsu, unpublished). A weed sample was selected for further testing to determine whether that species was a possible host of IYSV in New York if the OD reading from the DAS-ELISA for the sample was greater than three times the mean OD reading for the IYSV-negative control samples for that plate. Weed species were considered hosts for IYSV only if the plant tissue samples from that species reacted positively for IYSV by DAS-ELISA, and the samples yielded a DNA amplicon of appropriate size for the small RNAencoded nucleocapsid (N) gene in reverse-transcription (RT)-poly- merase chain reaction (PCR) or immunocapture (IC)-RT-PCR assays, as described below. Results are presented as a binomial; each weed species was classified as positive or negative for IYSV based on the results from serological and molecular tests.

Detection of IYSV by RT-PCR-based assays. A segment of the IYSV small RNA-encoded N gene was characterized by RT-PCR for a subset of the onion and weed samples that reacted positively for IYSV by DAS-ELISA in 2007. The incidence of plants of each species that reacted positively for IYSV by DAS-ELISA and ICRT-PCR was not recorded because the objective was only to verify whether a particular species was a host for the virus. For each sample, total extracted RNA and 50 pmol of the IYSV-specific reverse primer (5'-ACTCACCAATGTCTTCAAC-3') and forward primer (5'-GGCTTCCTCTGGTAAGTGC-3') were used. Total RNA was extracted from leaf tissue $(100 \mathrm{mg})$ that was disrupted with a TissueLyser homogenizer (Qiagen, Valencia, CA) for $2 \mathrm{~min}$ at 30 Mhz in the presence of one stainless-steel bead $(5 \mathrm{~mm}$ in diameter), after dipping the leaf tissue in liquid nitrogen. RNA was extracted using the RNeasy Mini Plant kit (Qiagen). A primer pair specific to the ribulose 1,5-bisphosphate carboxylase chloroplast gene $(R b c l)$ of plants (forward primer 5'-TACTTGAATGCT ACTGCAG-3' and reverse primer $5^{\prime}$-CTGCATGCATTGCAC GATC-3') was used as an internal control sample to amplify the corresponding mRNA of the plant sample in both standard and multiplex RT-PCR format. One-step RT-PCR was carried out using the Access System (Promega Corp., Madison, WI) with Avian myeloblastosis virus RTase, Tfl DNA polymerase, and $50 \mathrm{pmol}$ of specific primers in a 50- $\mu$ l final volume, according to the manufacturer's protocol. Single-tube RT-PCR used a 45-min heating step at $45^{\circ} \mathrm{C}$ and a 15 -min heating step at $94^{\circ} \mathrm{C}$; followed by 30 cycles of 1 min of melting at $94^{\circ} \mathrm{C}, 1 \mathrm{~min}$ of annealing at $50^{\circ} \mathrm{C}$, and $2 \mathrm{~min}$ of elongation at $72^{\circ} \mathrm{C}$; with a final extension of 7 min at $72^{\circ} \mathrm{C}$.

In 2008 and 2010, a subset of weed samples that reacted positively for IYSV by DAS-ELISA was also assayed for IYSV by ICRT-PCR to characterize a segment of the small RNA-encoded N gene. Virus particles were immunocaptured by loading leaf extracts in microfuge tubes precoated with antibodies specific to IYSV (Agdia, Inc.). After three washes with phosphate-buffered saline supplemented with $5 \%$ Tween 20 , virus particles were suspended in $10 \mu \mathrm{l}$ of sterile water, denatured by heating for $5 \mathrm{~min}$ at $70^{\circ} \mathrm{C}$, and chilled on ice. The suspension $(1 \mu \mathrm{l})$ was used in an RT-PCR assay for each sample, as described above. The reaction products of both types of RT-PCR assays were resolved by electrophoresis in $1.5 \%$ agarose gels in $90 \mathrm{mM}$ Tris-borate and $2 \mathrm{mM}$ EDTA at $\mathrm{pH}$ 8.0 , and subsequently visualized under UV light after staining with ethidium bromide.

IYSV sequence determination and analysis. The 402-bp IYSV amplicons obtained by RT-PCR or IC-RT-PCR from onion and weed samples were extracted from agarose gels with the QIAquick purification kit (Qiagen) and sequenced bidirectionally using the Big Dye Terminator kit, AmpliTaq-FS DNA polymerase, and an Applied Biosystems Automated 3730xl DNA Analyzer at the DNA Sequencing facility at Cornell University in Ithaca, NY. Three to five IYSV cDNA amplicons were sequenced for each onion and weed sample. Sequences were analyzed and compared using the DNASTAR Lasergene software (version 7.2). The program CLUSTAL W was used for alignment of nucleotide sequences (51).

Thrips on transplants and volunteer onion plants. From the pool of 900 onion transplants collected in April 2007, 50 plants representing each of 12 cultivars (600 plants total) were placed in separate plastic storage bins, 1 cultivar/bin, with a thrips-proof screen mesh on the top of each bin. Plants were held for 2 weeks at $25^{\circ} \mathrm{C}$ and $53 \%$ relative humidity with a light-and-dark cycle 16 and $8 \mathrm{~h}$, respectively, to allow thrips larvae to emerge and complete development. Live and dead larval and adult thrips were counted on each plant from 6 to 8 May 2007 but were not identified to species. In June 2009, 25 volunteer onion plants emerging in nonrotated onion fields in Yates $(n=1)$ and Genesee/Ontario $(n=5)$ 
Counties were flagged. Adult and larval T. tabaci on each plant were counted four times between 4 June and 6 July 2009 to estimate when overwintering adults started colonizing volunteers and to track population densities for the first generation of larvae.

\section{Results}

Transplant onion samples. None of the 1,097 samples of onion transplants tested in 2007 reacted positively for IYSV by DASELISA (Table 1). In 2008, 4 of $760(0.53 \%)$ samples reacted positively to IYSV antibodies, representing 3 of the 12 (25\%) cultivars tested: 'Norstar', 'Prince', and 'T-439' (Table 1). For Norstar, 1 of 120 samples tested positive; for Prince, 2 of 60 samples tested positive; and for T-439, 1 of 60 samples tested positive. The estimated incidence of IYSV-infected transplants, depending on whether one or all five plants in the five-plant composite samples were infected, was 0.17 to $0.83 \%$ for Norstar, 0.67 to $3.30 \%$ for Prince, and 0.33 to $1.67 \%$ for T- 439 . The four positive samples had transformed OD readings ranging from 5.69 to 5.76, slightly greater than the threshold of 5.67 that separated the "positive" samples from the "negative" samples (Fig. 1).

Volunteer onion plants from fields and cull piles. In 2007, 4 of the $231(1.7 \%)$ field volunteer plants reacted positively for IYSV by DAS-ELISA, and these plants were located in 3 of the 10 $(30 \%)$ fields sampled. In those three fields, the average incidence of IYSV in volunteer plants was $4.5 \%$ /field (range: 2.5 to $6.7 \%$; Table 2). In 2008, 9 of the 578 (1.6\%) field volunteer plants tested positive for IYSV by DAS-ELISA, and these plants were located in 4 of the $27(15 \%)$ fields sampled. In those four fields, the average incidence of IYSV was $11.1 \%$ /field (range: 3.3 to $17.6 \%$; Table 2). IYSV was found more frequently in volunteer onion plants growing in cull piles than in nonrotated onion fields. In cull piles, 14 of the $359(3.9 \%)$ cull pile volunteer plants tested positive for IYSV by DAS-ELISA, and these plants were located in 6 of the $12(50 \%)$ cull piles sampled. The average incidence of IYSV for volunteers in those six cull piles was $7.8 \%$ /cull pile (range: 3.3 to $16.7 \%$; Table 2).

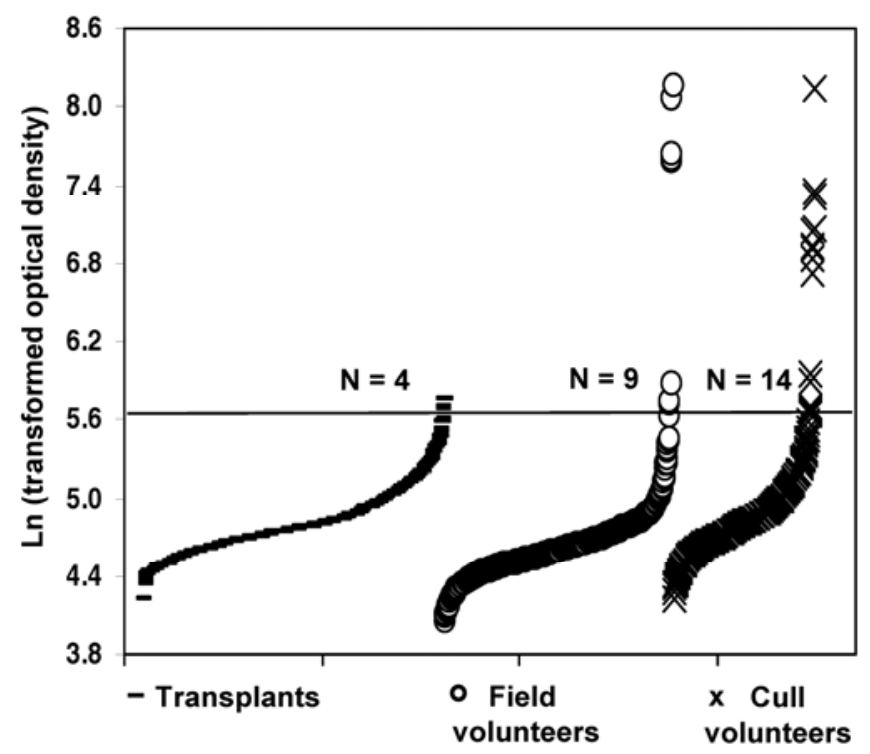

Fig. 1. Distribution of transformed optical density (OD) readings for onion plant samples that were tested in 2008 for Iris yellow spot virus (IYSV) using a double-antibody sandwich enzyme-linked immunosorbent assay (DAS-ELISA). Transplant samples were bare-root onion transplants imported into New York State from Arizona. Field volunteers were onion volunteer plants collected in New York onion fields. Cull volunteers were onion volunteer plants collected from New York cull piles. The transformed OD reading separating negative from positive samples had a threshold of 5.67 , with the number of samples above this threshold $(\mathrm{N})$ indicated on the graph. OD readings were transformed by standardizing samples on each plate by subtracting the mean OD reading of the negative control samples for that plate from each sample on the plate, and then using $\ln$ ([standardized sample OD reading $\times 1,000]+100$ )
Weed samples. Samples of 4 of the $17(23.5 \%)$ weed species reacted positively for IYSV by DAS-ELISA (Table 3). In 2007, tissue samples from both common burdock and dandelion plants, the only weed species tested that year, tested positive for IYSV by DAS-ELISA (Table 3). In 2008, only tissue samples from chicory (Cichorium intybus L.), common burdock, curly dock (Rumex crispus L.), and dandelion plants reacted positively (Table 3); none of the plants sampled for the other 13 weed species tested positive for IYSV. In 2010, tissue samples from common burdock collected from Yates County reacted positively. IC-RT-PCR was used to confirm the presence of IYSV in chicory, common burdock, curly dock, and dandelion (Fig. 2).

IYSV confirmation in weeds by sequencing. Viral cDNA amplicons obtained by IC-RT-PCR from onion and weed samples were sequenced directly without cloning. Partial IYSV N gene nucleotide sequences from chicory, curly dock, and dandelion were 98.9 to $99.3 \%$ identical. Additional sequence analyses indicated 98.6 to $99.7 \%$ identity at the nucleotide level between IYSV isolates from the New York onion and weed samples and corresponding isolates from onion plants collected in other states of the United States (i.e., California, GenBank accession no. FJ713700; Colorado, GenBank accession no. DQ233477; Georgia, GenBank accession no. DQ838594; Idaho, GenBank accession no. DQ233472; Nevada, GenBank accession no. FJ713699; Texas, GenBank accession no. DQ658242; Utah, GenBank accession no. DQ233478; and Washington, GenBank accession no. DQ233468) as well as the sequence of an isolate from Brazil (GenBank accession no. AF067070)

Thrips on transplants and volunteer onion plants. Transplants sampled from 11 of the 12 cultivars examined in 2007 were infested with thrips. Dead thrips were more abundant than live thrips: 53 dead thrips were found on transplant samples representing 10 of the 12 cultivars; and 21 live thrips, 12 larvae, and 9 adults were found on transplant samples representing 6 of the 12 cultivars (Table 4). Transplants had 0 to 0.30 total thrips/plant and, for the six cultivars with live thrips, densities ranged from 0.02 to 0.16 live thrips/plant (Table 4). 'Sherman' had the greatest total number of thrips ( 0.30 thrips/plant) and the greatest number of live thrips (0.16 live thrips/plant). 'Red Wing' was the only cultivar on which thrips were not observed. Averaged across all samples, the mean number of total thrips per plant was 0.11 , and the mean number of live thrips per plant was 0.03 (Table 4).

Thrips densities on volunteer onion plants monitored in onion fields in 2009 in New York varied among fields. Volunteer onion plants from the field in Yates County (Fig. 3A) had much greater thrips densities than volunteer plants from all five fields examined in Genesee/Orleans Counties (Fig. 3B and C). In Yates County, mean larval thrips populations on volunteer plants increased to 32.2 larvae/plant on 16 June, then declined to $5.4 /$ plant by 22 June, whereas the adult thrips populations increased slightly on 10 June to 7.4 adults/plant, then declined to 2.8 /plant by 22 June (Fig. $3 \mathrm{~A}$ ). In Genesee/Orleans Counties, larval thrips counts peaked on 11 June in all five fields, with the greatest densities in field 5 (12.3 larvae/plant) and field 2 (8.7 larvae/plant), then declined in all

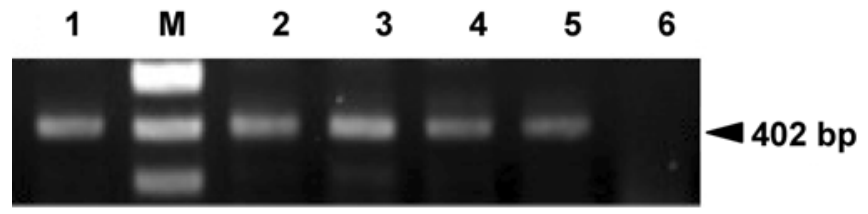

Fig. 2. Agarose gel analysis of cDNA amplicons obtained by immunocapture-reverse transcription-polymerase chain reaction (IC-RT-PCR) from RNA extracts of dry bulb onion and weed samples infected with Iris yellow spot virus (IYSV). Lane 1, Onion plant; lane 2, dandelion; lane 3, chicory; lane 4, curly dock; lane 5, common burdock; and lane 6, healthy onion (see Table 3 for Latin binomials). Lane M, 100 bp DNA size standard (New England Biolabs Inc., Ipswich, MA). DNA products were resolved by electrophoresis on a $1.5 \%$ agarose gel. The size of the amplicon is indicated with an arrow. 
fields to $<0.1$ larvae/plant by 6 July (Fig. 3B). Adult thrips densities started relatively low; all fields had $<1.0$ adult thrips per plant in early June. Adult thrips densities decreased steadily in four of the five fields to 0 adult thrips/plant by 6 July. Field 5 was the exception; populations in field 5 increased to 3.3 adults/plant on 11 June and then, similar to the other four fields, declined to $0 /$ plant by 6 July (Fig. 3C).

\section{Discussion}

All four categories of potential plant hosts of IYSV tested in this study were confirmed as possible sources for IYSV in New York State. IYSV-infected onion transplants shipped into New York from Arizona, as well as infected volunteer onion plants sampled in fields and from cull piles within New York, are potential earlyseason sources of IYSV and hosts for Thrips tabaci. Common burdock is a biennial weed, and chicory, curly dock, and dandelion are perennial weeds that tested positive for IYSV using both a DAS-ELISA and IC-RT-PCR assay. These biennial and perennial weeds could play a role as overwintering hosts if IYSV can survive in dormant tissues until spring, and as reservoirs of the virus during the onion growing season. To our knowledge, this is the first report of IYSV in these weed species.

At the start of these experiments, there was no information available on whether onion transplants imported into New York might be infected with IYSV. Work by Schwartz et al. (46) over a 4-year period demonstrated that IYSV incidence in onion transplants originating from Arizona, California, and Texas and shipped into Colorado ranged from 0 to $56 \%$. Only plants with IYSV-type symptoms were analyzed in their studies and, within a sample, up to $5 \%$ of the plants tested using serological methods were positive for IYSV (46). Transplants tested in this study were not selected based on the presence or absence of IYSV symptoms. Of 1,097 samples, each consisting of five transplants/sample for a total of 5,485 plants tested in 2007, not one was considered positive for IYSV. In 2008, of the 760 transplant samples tested, 3,800 plants in total, 4 samples $(0.53 \%)$ tested positive for IYSV by DASELISA. Within cultivars, IYSV incidence in transplants ranged from 0.17 to $3.30 \%$, which was slightly lower than the $5 \%$ maximum found by Schwartz et al. (46) for transplants shipped into Colorado. Though these incidence rates are relatively low, the potential importance of transplants as a recurring source of new introductions of IYSV into New York should not be underestimated.

IYSV is not uniformly distributed within Allium hosts and the virus is not reliably detected by DAS-ELISA in all of the leaves of an infected plant $(15,25,48)$. In preliminary studies, we observed that an onion leaf inoculated with IYSV did not always react posi- tively for IYSV by DAS-ELISA, even when leaves interior to the inoculated leaf reacted positively (C. Hsu, unpublished). IYSV was detected in either the inoculated leaf or a leaf interior to the inoculated leaf; older leaves on the same plant did not react positively (C. Hsu, unpublished). This spatial heterogeneity of IYSV within onion plants could result in false negative results when using serological tests, resulting in an underestimation of the true incidence of IYSV.

Schwartz et al. (46) found a range in thrips densities on onion transplants imported into Colorado from Texas, Arizona, and California: 0.10 to 0.36 thrips/transplant originating from Texas, 0.01 to 1.26 thrips/transplant originating from Arizona, and 0.23 to 4.54 thrips/transplant originating from California. The most consistent thrips species recovered was $T$. tabaci, found each year on transplants from all three states (46). In this study, thrips densities on transplants coming into New York from Arizona ranged from 0 to 0.30 total thrips/plant and 0.02 to 0.16 live thrips/plant. This is within the range of thrips densities reported by Schwartz et al. (46) but below the maximum number of thrips per plant found in that study. We did not identify thrips to species in this study, and additional work is planned to determine whether viruliferous $T$. tabaci can be carried on imported onion transplants.

The presence of IYSV in transplants suggests that fields grown using onion transplants might have a higher incidence of IYSV than fields grown from seed, because IYSV is not known to be seed transmitted $(25,40)$. Studies conducted in New York onion fields in 2007 and 2008 revealed no difference in the progression of IYSV in fields established using transplants compared with fields planted using seed (21). By harvest, IYSV incidence was significantly higher in direct-seeded fields compared with fields planted using imported bare-root transplants (21). This suggests that, although transplants may be important in introducing new inoculum into New York each year, the temporal dynamics of IYSV in direct-seeded crops versus transplanted crops may be similar. Nonetheless, introducing low levels of new inoculum into the cropping system could affect the epidemiology of the disease. Repeated introductions of inoculum could allow the virus to persist even if the virus could be eradicated locally.

Introduction of novel isolates of IYSV could also have long-term consequences on virus-vector interactions if an introduced isolate is more virulent or affects $T$. tabaci transmission rates for IYSV. There are known differences in thrips competence for transmission of Tospovirus spp. depending on the virus isolate (50). For example, T. tabaci is a vector of Tomato spotted wilt virus (TSWV) in the genus Tospovirus, family Bunyaviridae, but is incapable of transmitting some isolates of TSWV in some areas (4). Populations

Table 4. Number of bare-root onion transplants imported from Arizona into New York in 2007 that were examined for thrips larvae and adults, and number of dead and live thrips observed

\begin{tabular}{|c|c|c|c|c|c|c|}
\hline \multirow[b]{2}{*}{ Cultivar } & \multicolumn{6}{|c|}{ Number of } \\
\hline & Plants sampled $^{\mathrm{a}}$ & Dead thrips $^{b}$ & Live larvae & Live adults & Total thrips/plant ${ }^{\mathrm{c}}$ & Live thrips/plant \\
\hline \multicolumn{7}{|l|}{ Yellow bulb } \\
\hline Empire Sweet & 51 & 6 & 0 & 0 & 0.12 & 0 \\
\hline Frontier & 50 & 1 & 0 & 0 & 0.02 & 0 \\
\hline Milestone & 50 & 0 & 1 & 1 & 0.04 & 0.04 \\
\hline Norstar & 100 & 8 & 0 & 4 & 0.12 & 0.04 \\
\hline Prince & 50 & 1 & 0 & 0 & 0.02 & 0 \\
\hline Ricochet & 50 & 11 & 0 & 0 & 0.22 & 0 \\
\hline Sherman & 50 & 7 & 8 & 0 & 0.30 & 0.16 \\
\hline $\mathrm{T}-439$ & 50 & 4 & 0 & 1 & 0.10 & 0.02 \\
\hline \multicolumn{7}{|l|}{ Red bulb } \\
\hline Mercury & 51 & 7 & 0 & 0 & 0.14 & 0 \\
\hline Red Bull & 50 & 4 & 1 & 1 & 0.12 & 0.04 \\
\hline Red Wing & 50 & 0 & 0 & 0 & 0 & 0 \\
\hline Red Zeppelin & 50 & 4 & 2 & 2 & 0.16 & 0.08 \\
\hline Total & 652 & 53 & 12 & 9 & 0.11 & 0.03 \\
\hline
\end{tabular}

a Transplants were examined for thrips before planting to ensure that thrips originated from Arizona.

${ }^{b}$ Total number of dead larval and adult thrips.

${ }^{c}$ Average number of dead and live thrips/plant. Thrips were not identified to species.

d Average number of live larval and adult thrips/plant. 
of thrips collected from different locations can also differ in ability to transmit the same isolate of a Tospovirus sp. $(3,55,57)$. Inoue et al. (22) found significant differences in transmission efficiencies between five populations of T. tabaci infected with the same IYSV isolate. Stumpf and Kennedy (49) found isolate-specific interactions between host plants and temperature on TSWV transmission rates, and suggested that these interactions could favor the spread of one isolate over another depending on environmental conditions. There is also recent evidence that vector competence may be under genetic control $(3,19)$. The coevolutionary relationship between thrips and Tospovirus spp. may explain why differences in vector competence exist among source populations of thrips and among virus isolates (56).

In addition, differences in transmission efficiency of Tospovirus spp. exist between male and female thrips (5). T. tabaci is a complex species and populations can be dominated by one of three reproductive modes: thelytoky, the production of unfertilized females by females; arrhenotoky, the production of males from unfertilized eggs and females from fertilized eggs; and deutoerotoky, the production of males and females by unfertilized eggs (34). Recent studies have shown that male T. tabaci are more efficient than females at transmitting TSWV (5). Studies have also demonstrated that male western flower thrips, Frankliniella occidentalis (Pergande), another vector of TSWV, are more efficient at transmitting TSWV than females $(42,54)$. Differences in transmission efficiency of TSWV by $F$. occidentalis may be the result of sexually dimorphic feeding behaviors (54). In New York, T. tabaci populations in June and July are primarily thelytokous, with very few males produced. By August, the populations shift to primarily arrhenotokous or deuterotokous (34). Data on the temporal spread of IYSV in New York showed that the incidence of IYSV stayed relatively stable and low in June and July, then increased dramatically in August (21). Research is needed to determine whether the late-season increase in IYSV incidence in New York is related to a shift in $T$. tabaci populations to male-producing reproductive modes.

The presence of IYSV in volunteer onion plants in fields and cull piles ensures a source of IYSV inoculum in New York onion fields each spring, even in the absence of imported infected transplants. Over 2 years, 14.8 to $30.0 \%$ of the fields sampled in this study had volunteer onion plants that tested positive for IYSV by DAS-ELISA. Volunteer onion plants are removed by hand early in May and June in most fields, but not all growers are diligent in this cultural practice. Data presented in this study on the temporal dynamics of $T$. tabaci on volunteer plants indicate that adults colonized volunteer onion plants by early June, and first-generation larvae had the greatest densities in mid-June. These volunteer plants would need to be removed from fields by late May to early June to prevent first-generation T. tabaci larvae from completing development on infected volunteer plants and producing viruliferous adults that could spread the virus from volunteers into the onion crop.

The greater percent of cull piles with at least one volunteer onion plant infected with IYSV (50\%) compared with fields in which at least one volunteer plant was infected (14.8 to 30.0\%) and, across all volunteer onion plants sampled in this study, the greater average percentage of infected volunteer onion plants in cull piles (3.9\%) compared with infected volunteer onion plants in fields (1.6 to $1.7 \%$ ) may be the result of concentrating IYSV-infected bulbs in cull piles. Onion bulbs that are misshapen, rotten, or too small to be marketable are removed during the grading process and disposed of in cull piles. One of the major impacts of IYSV on onion bulb yields is downgrading of bulb size, rather than a decrease in the number of bulbs $(11,16,47)$. This could result in a greater proportion of small bulbs infected with IYSV compared with larger bulbs, and the smaller bulbs are more likely to be culled, potentially increasing the incidence of IYSV in cull piles. Research is needed to validate this hypothesis.

Similar to locally grown bulbs, imported bulbs are graded and the culled bulbs are discarded into cull piles. Cull piles associated with onion packing houses that import bulbs and repack them in New York may play an important role in the epidemiology of IYSV because imported bulbs are another potential source of novel IYSV isolates, like imported onion transplants. For example, it has been suggested that IYSV entered Georgia through the importation of Peruvian bulbs, and that IYSV-infected thrips originating on culled Peruvian bulbs spread IYSV to nearby onion seedlings and production fields (36). A phylogenetic analysis of the $\mathrm{N}$ gene sequence of IYSV showed that Georgia and Peruvian isolates of IYSV fell into the same clade, and were genetically distinct from other IYSV isolates identified in the western United States (36). Onion bulbs imported into New York have not been tested to determine whether any of the bulbs arrive infected or harbor viruliferous thrips, or whether imported bulbs could be a source of origin for IYSV isolates currently present in New York.

Unlike volunteer onion plants emerging in fields, however, most cull piles in New York are geographically isolated from commercial onion fields and remain in the same location for many years (B. Nault, personal communication). In New York, viruliferous thrips would have to travel a greater distance from cull piles to colonize a commercial onion field compared with viruliferous thrips dispersing from volunteers growing within or along the edges of nonrotated commercial onion fields. Though cull piles had a greater incidence of infected volunteer plants compared with
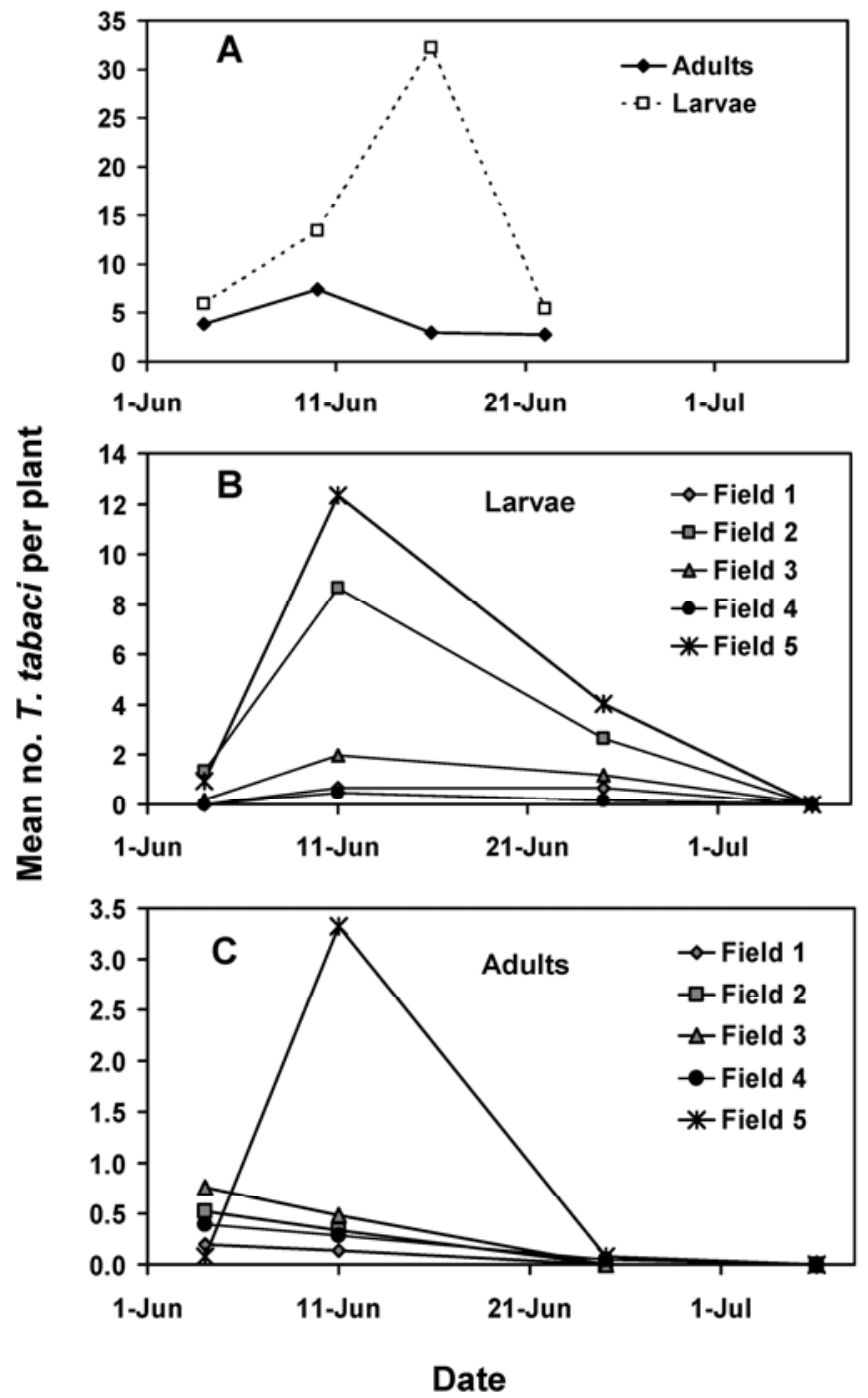

Fig. 3. A, Mean density of onion thrips, Thrips tabaci, larvae and adults found on volunteer onion plants in one onion field in Yates County, New York and mean densities of $\mathbf{B}$, larvae and $\mathbf{C}$, adults found in five onion fields in Genesee/Orleans Counties, New York, in 2009. Twenty-five plants were flagged, numbered, and sampled from June through July in each field. 
volunteers in onion fields in this study, the relative importance of cull pile volunteers may be diminished by the greater isolation of these virus reservoirs from commercial production fields. In general, the density of insects colonizing a field from a point source, such as a cull pile, decreases with increasing distance from the source. Coutts et al. (8) found a steep decline in TSWV incidence with increasing distance from external sources of TSWV, and suggested that 75 to $100 \mathrm{~m}$ was a "safe" planting distance from a TSWV source of infection for crops such as pepper. Latham and Jones (26) suggested that $23 \mathrm{~m}$ was a safe planting distance to successfully limit dispersal of viruliferous thrips from potential sources of TSWV into pepper crops. There are situations in New York where cull piles are located within $100 \mathrm{~m}$ of commercial onion fields (B. Nault, personal communication). In those cases, adjacent onion crops may be at a higher risk for IYSV infection. In general, it is recommended that onion growers locate cull piles as far from production fields as possible to minimize immigration of viruliferous thrips from cull piles into onion crops.

The role of weeds in the epidemiology of IYSV in New York may depend, in part, on whether T. tabaci can complete development on these alternate host plants. IYSV is reported to occur naturally in more than 21 non-Allium plant species (44), not including the four new species reported in this study. In order for an alternative IYSV plant host to play a role in persistence of the virus, the plant must also be a reproductive host for T. tabaci. Early instars of T. tabaci are limited in mobility and cannot travel far from the natal host plant. Plants reported to be naturally infected with IYSV would be "dead-end" hosts for the virus if T. tabaci did not lay eggs on the plant, if larvae did not feed on the plant long enough to acquire the virus, or if infected larvae did not survive to become adults.

Research on the TSWV pathosystem has identified many weed species that can serve as alternate hosts for both TSWV and thrips vectors of TSWV $(5,17,18,29)$. Weeds serve as a green bridge, enabling TSWV to persist in the absence of a crop host, and as an external and within-crop source for spread of TSWV during crop development (24). However, not all weed species that are hosts for both TSWV and thrips vectors are equal in importance. Different weed species can have different infection rates (18), and there may be significant differences in how infection rates decline over time among weed species (17). Thrips that complete development on an infected weed have different transmission rates depending on the host weed species $(5,18,49)$, and some weed species support consistently greater populations of immature thrips than others and have a greater potential to generate viruliferous adults $(5,17,18)$. Additional research is needed to estimate T. tabaci efficiencies in acquisition of IYSV from different weed species and efficiencies in transmission of IYSV from weed hosts to onion plants before the relative importance of weeds in New York's onion-IYSV pathosystem can be assessed.

IYSV was first detected in New York in 2006 (20), the first year any effort was made to look for the virus in New York. Since then, IYSV has been found consistently in New York $(21,32)$. So far, New York onion crops have not suffered the extreme losses that many of the southwest and western states have reported from IYSV $(11,15)$. However, mean bulb weights for onion plants that tested positive for IYSV using DAS-ELISA in 2009 were approximately 7 to $25 \%$ lower than bulb weights of onion plants that tested negative for IYSV (32). This was consistent for crops grown from seed or onion transplants and for two cultivars, 'Milestone' (yellow) and 'Red Bull' (red) (32). A decrease in bulb weight due to IYSV infection could have a significant economic impact on New York onion growers.

Results presented in this study add to basic epidemiological information on the onion-IYSV-T. tabaci pathosystem. In New York, onion transplants and volunteer onion plants are now confirmed as potential early-season sources of IYSV, though the relative importance of these sources in epidemics of the virus in commercial onion fields remains to be quantified. In addition, imported onion transplants and imported bulbs may introduce novel IYSV isolates into New York that could have the potential of causing more severe losses within the onion-IYSV pathosystem in New York than established isolates. The relative importance of volunteer onion plants and weeds as reservoirs that enable the virus to survive between cropping seasons is still under investigation. Additional work is needed to determine whether viruliferous adult thrips that enter diapause in the fall and overwinter in New York are capable of transmitting IYSV the following spring, and whether the shift in $T$. tabaci reproductive modes during the crop season has any effect on the epidemiology of IYSV in New York. Management strategies to minimize the negative impacts of IYSV in New York's onion production system can be improved by understanding these factors.

\section{Acknowledgments}

This work was supported, in part, by the New York Farm Viability Institute and the New York State Onion Research and Development Program. We thank R. Cox, P. Fox, M. L. Hessney, C. MacNeil, P. Marsella-Herrick, E. Rockefeller, and $\mathrm{M}$. Ullrich for field assistance and laboratory assistance; and L. du Toit and two anonymous reviewers for their constructive comments.

\section{Literature Cited}

1. Anonymous. (Current). Common/ Scientific Names. Weed Science Society of America. http://www.wssa.net/Weeds/ID/WeedNames/namesearch.php

2. Brewster, J. L. 2008. Onions and other vegetable Alliums. In: Crop Production Science in Horticulture, 2nd ed. CAB International, Wallingford, UK.

3. Cabrera-La Rosa, J. C., and Kennedy, G. G. 2007. Thrips tabaci and tomato spotted wilt virus: inheritance of vector competence. Entomol. Exp. Appl. 124:161-166.

4. Chatzivassiliou, E. K. 2001. Thrips tabaci: an ambiguous vector of TSWV in perspective. Pages 69-75 in: Thrips, Plants, Tospoviruses: The Millennial Review; Thrips and Tospoviruses: Proc. 7th Int. Symp. Thysanoptera, Reggio Calabria, Italy.

5. Chatzivassiliou, E. K., Peters, D., and Katis, N. I. 2007. The role of weeds in the spread of Tomato spotted wilt virus by Thrips tabaci (Thysanoptera: Thripidae) in tobacco crops. J. Phytopathol. 155:699-705.

6. Cortês, I., Livieratos, I. C., Derks, A., Peters, D., and Kormelink, R. 1998 Molecular and serological characterization of Iris yellow spot virus, a new and distinct Tospovirus species. Phytopathology 88:1276-1282.

7. Cosmi, T., Marchesini, E., and Martini, G. 2003. Presence and spread of Tospovirus and thrips vectors in Veneto. Inf. Agrar. 59:69-72.

8. Coutts, B. A., Thomas-Carroll, M. L., and Jones, R. A. C. 2004. Patterns of spread of Tomato spotted wilt virus in field crops of lettuce and pepper: spatial dynamics and validation of control measures. Ann. Appl. Biol. 145:231245.

9. Crowe, F. J., and Pappu, H. R. 2005. Outbreak of Iris yellow spot virus in onion seed crops in central Oregon. Plant Dis. 89:105.

10. Doederlein, T. A., and Sites, R. W. 1993. Host plant preference of Frankliniella occidentalis and Thrips tabaci (Thysanoptera: Thripidae) for onions and associated weeds on the Southern High Plains. J. Econ. Entomol. 86:1706-1713.

11. du Toit, L., and Pelter, G.Q. 2005. Susceptibility of storage onion cultivars to iris yellow spot in the Columbia Basin of Washington, 2004. Biol. Cult. Tests 20:V006

12. du Toit, L., Pelter, G., and Pappu, H. 2004. IYSV challenges to the onion seed industry in Washington. Pages 213-217 in: Proc. 2004 Nat. Allium Res. Conf. Grand Junction, CO.

13. Evans, C. K., Bag, S., Frank, E., Reeve, J. R., Ransom, C., Drost, D., and Pappu, H.R. 2009. Green foxtail (Setaria viridis), a naturally infected grass host of Iris yellow spot virus in Utah. Plant Dis. 93:670.

14. Gangloff, J. L. 1999. Population Dynamics and Insecticide Resistance of Onion Thrips, Thrips tabaci Lindeman (Thysanoptera: Thripidae) in Onions. Ph.D. dissertation, Cornell University, Ithaca, NY.

15. Gent, D. H., du Toit, L. J., Fichtner, S. F., Mohan, S.K., Pappu, H. R., and Schwartz, H. F. 2006. Iris yellow spot virus: an emerging threat to onion bulb and seed production. Plant Dis. 90:1468-1480.

16. Gent, D. H., Schwartz, H. F., and Khosla, R. 2004. Distribution and incidence of Iris yellow spot virus in Colorado and its relation to onion plant population and yield. Plant Dis. 88:446-452.

17. Groves, R. L., Walgenbach, J. F., Moyer, J. W., and Kennedy, G. G. 2001. Overwintering of Frankliniella fusca (Thysanoptera: Thripidae) on winter annual weeds infected with Tomato spotted wilt virus and patterns of virus movement between susceptible weed hosts. Phytopathology 91:891-899.

18. Groves, R. L., Walgenbach, J. F., Moyer, J. W., and Kennedy, G. G. 2002 The role of weed hosts and tobacco thrips, Frankliniella fusca, in the epidemiology of Tomato spotted wilt virus. Plant Dis. 86:573-582.

19. Halaweh, N., and Poehling, H.-M. 2009. Inheritance of vector competence by the thrips Ceratothripoides claratris (Shumsher) (Thysantoptera: Thripidae). J. Appl. Entomol. 133:386-393.

20. Hoepting, C. A., Schwartz, H. F., and Pappu, H. R. 2007. First report of Iris yellow spot virus on onion in New York. Plant Dis. 91:327. 
21. Hsu, C. L., Hoepting, C. A., Fuchs, M., Shelton, A. M., and Nault, B. A. 2010. Temporal dynamics of Iris yellow spot virus and its vector, Thrips tabaci (Thysanoptera: Thripidae), in seeded and transplanted onion fields. Environ. Entomol. 39:266-277.

22. Inoue, T., Murai, Y., and Natsuaki, T. 2010. An effective system for detecting Iris yellow spot virus transmission by Thrips tabaci. Plant Pathol. 59:422-428.

23. Jones, D. R. 2005. Plant viruses transmitted by thrips. Eur. J. Plant Pathol. 113:119-157

24. Jones, R. A. C. 2004. Using epidemiological information to develop effective integrated virus disease management strategies. Virus Res. 100:5-30.

25. Kritzman, A., Lampel, M., Raccah, B., and Gera, A. 2001. Distribution and transmission of Iris yellow spot virus. Plant Dis. 85:838-842.

26. Latham, L. J., and Jones, R. A. C. 1997. Occurrence of tomato spotted wilt tospovirus in native flora, weeds, and horticultural crops. Aust. J. Agric. Res. 48:359-369.

27. McLachlan, G. J., and Peel, D. 2000. Finite Mixture Models. Wiley, New York.

28. Mohan, S. K., and Moyer, J. W. 2004. Iris yellow spot virus in onion seed and bulb crops. (Abstr.) Phytopathology 94:S153.

29. Morsello, S. C., and Kennedy, G. G. 2009. Spring temperature and precipitation affect tobacco thrips, Frankliniella fusca, population growth and Tomato spotted wilt virus spread within patches of the winter annual weed Stellaria media. Entomol. Exp. Appl. 130:138-148.

30. Nagata, T., Almeida, A. C. L., de O. Resende, R., and de Ávila, A. C. 1999. The identification of the vector species of Iris yellow spot tospovirus occurring on onion in Brazil. Plant Dis. 83:399.

31. Natwick, E. T., Byers, J. A., Chu, C., Lopez, M., and Henneberry, T. J. 2007. Early detection and mass trapping of Frankliniella occidentalis and Thrips tabaci in vegetable crops. Southwest. Entomol. 32:229-238.

32. Nault, B. A., Hsu, C. L., Smith, E. A., Hessney, M. L., Fuchs, M., and Shelton, A. M. 2010. Managing onion thrips and status of Iris yellow spot virus in New York. Pages 113-117 in: Proc. 2010 Empire State Fruit Veg. Expo, Syracuse, NY.

33. Nault, B. A., Hsu, C. L., Smith, E. A., Shelton, A. M., Fuchs, M., Hoepting, C. A., and DiTommaso, A. 2008. Identifying sources of Iris yellow spot virus in New York's onion cropping system. Pages 67-72 in: Proc 2008 Nat. Allium Res. Conf. Savannah, GA.

34. Nault, B. A., Shelton, A. M., Gangloff-Kaufmannn, J. L., Clark, M. E., Werren, J. L., Cabrera-La Rosa, J. C., and Kennedy, G. G. 2006. Reproductive modes in onion thrips (Thysanoptera: Thripidae) populations from New York onion fields. Environ. Entomol. 35:1264-1271.

35. Nischwitz, C., Gitaitis, R. D., Mullis, S. W., Csinos, A. S., Langston, Jr., D. B., and Sparks, A. N. 2007. First report of Iris yellow spot virus in spiny sowthistle (Sonchus asper) in the United States. Plant Dis. 91:1518.

36. Nischwitz, C., Pappu, H. R., Mullis, S. W., Sparks, A. N., Langston, D. R., Csinos, A. S., and Gitaitis, R. D. 2007. Phylogenetic analysis of Iris yellow spot virus isolates from onion (Allium cepa) in Georgia (USA) and Peru. J. Phytopathol. 155:531-535.

37. Pappu, H. R., Jones, R. A. C., and Jain, R. K. 2009. Global status of Tospovirus epidemics in diverse cropping systems: successes achieved and challenges ahead. Virus Res. 141:219-236.

38. Poole, G. J., Pappu, H. R., Davis, R. M., and Turini, T. A. 2007. Increasing outbreaks and impact of Iris yellow spot virus in bulb and seed onion crops in the Imperial and Antelope Valleys of California. Plant Health Prog. doi: 10.1094/PHP-2007-0508-01-BR.

39. Reiners, S. R., and Petzoldt, C. H. 2010. Integrated Crop and Pest Management Guidelines for Commercial Vegetable Production. Cornell Cooperative Extension, Ithaca, NY.

40. Robène-Soustrade, I., Hostachy, B., Roux-Cuvelier, M., Minatchy, J.,
Hédont, M., Pallas, R., Couteau, A., Cassam, N., and Wuster, G. 2006. First report of Iris yellow spot virus in onion bulb- and seed-production fields in Réunion Island. Plant Pathol. 55:288.

41. R-Project. 2008. R Version 2.8.1. http://www.r-project.org/

42. Sakuri, T., Murai, T., Maeda, T., and Tsumuki, H. 1998. Sexual differences in transmission and accumulation of tomato spotted wilt virus in its insect vector Frankliniella occidentalis (Thysanoptera: Thripidae). Appl. Entomol. Zool. 33:583-588.

43. Sampangi, R. K., Mohan, S. K., and Pappu, H. R. 2007. Identification of new alternative weed hosts for Iris yellow spot virus in the Pacific Northwest. Plant Dis. 91:1683.

44. Schwartz, H. F. 2009. Plant species infected with IYSV. http://www. alliumnet.com/IYSVandDiagnostics.htm

45. Schwartz, H. F., Gent, D. H., Fichtner, S. M., Khosla, R., Mahaffey, L. A., Camper, M. A., and Cranshaw, W. S. 2010. Spatial and temporal distribution of Iris yellow spot virus and thrips in Colorado onion fields. Plant Health Prog. doi10.1094/PHP-2010-0820-01-RS.

46. Schwartz, H. F., Otto, K., Szostek, S., Boateng, C., Cranshaw, W. S., Camper, M. A., and Mahaffey, L. 2008. Thrips and IYSV sources in Colorado onion production systems. Pages 44-47 in: Proc. 2008 Nat. Allium Res. Conf. Savannah, GA.

47. Shock, C. C., Feibert, E., Jensen, L., Mohan, S. K., and Saunders, L. D. 2008. Onion variety response to Iris yellow spot virus. HortTechnology 18:539-544.

48. Smith, T. N., Wylie, S. J., Coutts, B. A., and Jones, R. A. C. 2006. Localized distribution of Iris yellow spot virus within leeks and its reliable large-scale detection. Plant Dis. 90:729-733.

49. Stumpf, C. F., and Kennedy, G. G. 2005. Effects of tomato spotted wilt virus (TSWV) isolates, host plants, and temperature on survival, size, and development time of Frankliniella fusca. Entomol. Exp. Appl. 114:215-225.

50. Tedeschi, R., Ciuffo, M., Mason, G., Roggero, P., and Tavella, L. 2001 Transmissibility of four tospoviruses by a thelytokous population of Thrips tabaci from Liguria, northwestern Italy. Phytoparasitica 29:37-45.

51. Thompson, J. D., Higgins, D. J., and Gibson, T. J. 1994. CLUSTAL W: improving the sensitivity of progressive multiple sequence alignment through sequence weighting, position-specific gap penalties and weight matrix choice. Nucleic Acids Res. 22:4673-4680.

52. Ullman, D. E., Meideros, R., Campbell, L. R., Whitfield, A. E., Sherwood, J. L., and German, T. L. 2002. Thrips as vectors of tospoviruses. Adv. Bot. Res. 36:113-140.

53. van de Wetering, F., Goldbach, R., and Peters, D. 1996. Tomato spotted wilt Tospovirus ingestion by first instar larvae of Frankliniella occidentalis is a prerequisite for transmission. Phytopathology 86:900-905.

54. van de Wetering, F., Hulshof, J., Posthuma, K., Harrewijn, P., Goldbach, R., and Peters, D. 1998. Distinct feeding behavior between sexes of Frankliniella occidentalis results in higher scar production and lower tospovirus transmission by females. Entomol. Exp. Appl. 88:9-15.

55. van de Wetering, F., van der Hoek, M., Goldbach, R., Mollema, C., and Peters, D. 1999. Variation in tospovirus transmission between populations of Frankliniella occidentalis (Thysanoptera: Thripidae). Bull. Entomol Res. 89:579-588.

56. Whitfield, A. E., Ullman, D. E., and German, T. L. 2005. Tospovirus-thrips interactions. Annu. Rev. Phytopathol. 43:459-489.

57. Wijkamp, I., Almarza, N., Goldback, R., and Peters, D. 1995. Distinct levels of specificity in thrips transmission of Tospoviruses. Phytopathology 85:1069-1074.

58. Wijkamp, I., Goldbach, R., and Peters, D. 1996. Propagation of tomato spotted wilt virus in Frankliniella occidentalis does neither result in pathological effects nor in transovarial passage of the virus. Entomol. Exp. Appl. 81:285-292. 